\title{
Going beyond metaphtonymy: Metaphoric and metonymic complexes in phrasal verb interpretation ${ }^{1}$
}

\author{
Francisco José Ruiz de Mendoza Ibáñez and Alicia Galera-Masegosa \\ francisco.ruizdemendoza@unirioja.es / alicia.galera@unirioja.es
}

University of La Rioja, Spain

\begin{abstract}
A metaphor can combine with another metaphor, or a metonymy with another metonymy, into a single meaning unit, thus giving rise to either a metaphorical or a metonymic amalgam. The combination of a metaphor and a metonymy, as discussed in Goossens (1990) and Ruiz de Mendoza and Díez (2002), gives rise to so-called "metaphtonymy". Amalgams and metaphtonymy are cases of conceptual complexes. Several such complexes have been identified in previous studies (e.g. Ruiz de Mendoza and Díez 2002, Ruiz de Mendoza and Mairal 2011). Here we revisit such studies and postulate the existence of metaphoric chains as an additional case of metaphoric complex in connection to the semantic analysis of phrasal verbs. Metaphoric chains, unlike amalgams (Ruiz de Mendoza and Mairal 2011), do not involve integrating the conceptual structure of the combined metaphors. Instead, metaphoric chains involve a mapping sequence in which the target domain of a first metaphoric mapping constitutes the source domain of a subsequent metaphor.
\end{abstract}

Keywords: metaphor, metonymy, metonymic chains, phrasal verb, metaphoric amalgams, metaphoric chains

\section{INTRODUCTION}

Phrasal verbs can be studied from a constructional perspective as form-meaning pairings where form cues for meaning activation and meaning is non-compositional (Dirven 2001). Because of their formally fixed and (at least partially) non-compositional semantic nature, phrasal verbs can be considered a special category of idiomatic expression, and their analysis has consequently been regarded as subsidiary to that of idiomatic expressions (cf. Kuiper and Everaert 2004, Makkai 1972).

The Cognitive Linguistics approach to metaphor and metonymy provides an explanatorily elegant framework to account for much of the meaning underlying idiomatic interpretation (cf. Hampe 2000). In this framework, the point of departure is the assumption that the meaning of phrasal verbs is mostly non-arbitrary but largely predictable and therefore sensitive to the use of cognitive operations in their interpretation (cf. Galera-Masegosa 2010, Langlotz 2006). Kövecses and Szabó (1996) 
offer an insightful contribution to the analysis of idiomatic expressions through metaphor. However, there are many cases in which idiomatic interpretation -including phrasal verb interpretation- often requires more complex analytical machinery than simply postulating single metaphors. For much idiomatic use, it may prove fruitful to study patterns of interaction involving metaphor and metonymy. These interactions were firstly addressed in Goossens' (1990) pioneering work. More recent studies have provided more refined and systematic patterns of interaction between metaphor and metonymy (cf. Ruiz de Mendoza and Díez 2002). However, our corpus of analysis suggests that further developments are needed in order to fully account for the complexities of phrasal verb interpretation. We thus incorporate into our set of explanatory tools the following conceptual interaction phenomena involving metaphor and metonymy:
a. Metaphor-metonymy interaction patterns
b. Metonymic complexes
c. Metaphoric complexes: amalgams and chains

We argue that the phenomena in (b) are essentially lexical although they may also motivate some grammatical phenomena (e.g. categorial conversion of a noun into a verb). Only the phenomena in (a) and (c) can underlie idiomatic expressions: while those in (a) account for situational idiomatic expressions, the ones in (c) seem to be specific to the meaning make-up of phrasal verb constructions.

Within this framework, we aim to provide a detailed picture of the various conceptual interaction phenomena identified above. Section II revisits the most relevant approaches that regard metaphor and metonymy as conceptualizing mechanisms. In section III we account for the different ways in which metaphor and metonymy may interact with each other. We also identify several metonymy-metonymy and metaphor-metaphor combination patterns. We critically review existing accounts and make new proposals on the topic. In addition, we present metaphoric chains as a new way in which two metaphors may combine, which has proved to be essential in phrasal verb interpretation. In this pattern of interaction the target of a first metaphor constitutes the source of a new metaphoric mapping whose target domain reveals the overall meaning of the expression. Section IV summarizes the main findings of our study. 


\section{METAPHOR AND METONYMY REVISITED}

\section{II.1. Conceptual Metaphor Theory (CMT)}

\section{II.1.1. Earlier version}

Conceptual Metaphor Theory (CMT) was first proposed by Lakoff and Johnson (1980) and developed by Lakoff and a number of associates (e.g. Gibbs 1994, Gibbs et al. 1997, Kövecses 1990, 2000, 2002, 2005, Lakoff 1987, Lakoff and Johnson 1999, Lakoff and Turner 1989). Challenging traditional views of metaphor as an embellishing device mainly used within the realms of literature, CMT claims that metaphor is not primarily a matter of language but of cognition: people make use of some concepts to understand, talk and reason about others. In this context, metaphor is described as a “conceptual mapping” (a set of correspondences) from a source domain (traditional vehicle) to a target domain (traditional tenor). The source is usually less abstract (i.e. more accessible to sense perception) than the target.

At the first stages of development of CMT, some preliminary efforts were made to classify metaphors. Lakoff and Johnson (1980) put forward a division between ontological, structural, and orientational metaphor. A few years later, Lakoff and Turner (1989) added image metaphors and redefined ontological in terms of a folk model about nature called the Great Chain of Being, which specifies physical and behavioral attributes of human beings, animals, plants, natural objects, and artifacts. Here are some examples of well-known conceptual metaphors together with a specification of their main correspondences, as discussed in the Cognitive Linguistics literature:

LOVE IS A JOURNEY: lovers are travelers; the love relationship is a vehicle; lovers' common goals are the destination; difficulties in the relationship are impediments to motion; etc. (e.g. But even without such problems, we often find ourselves spinning our wheels in dead-end relationships ${ }^{2}$ ).

ANGER IS HEAT: an angry person is a (generally pressurized) container that holds a hot substance (the anger) in its interior; the pressure of the substance on the container is the force of the emotion on the angry person; keeping the substance inside the container is controlling the anger; releasing the substance is the expression of anger; external signs of heat are external signs of anger (e.g. I find 
that my blood starts to boil when a person complains about the state of the local economy and has two foreign cars in their driveway $\left.?^{3}\right)$.

THEORIES ARE BUILDINGS: theories can be built, pulled down, demolished, buttressed, etc.; building tools are instruments to formulate a theory; building materials are elements in the theory (e.g. Yet his longer addresses depended upon powerfully built paragraphs to construct rock-solid arguments ${ }^{4}$ ).

ARGUMENT IS WAR: we see arguing as engaging in battle, people arguing as enemies, arguments as weapons, and winning or losing as military victory or defeat respectively (e.g. You're going to have to defend your theory rather than getting on the offensive $e^{5}$ ).

\section{II.1.2. Later version}

In recent years, Lakoff and Johnson (1999) have argued for the integration of Christopher Johnson's (1999) theory of conflation, Grady's (1997) theory of primary metaphor, Narayanan's (1997) neural theory of metaphor, and Fauconnier and Turner’s (1996, 2002) theory of conceptual blending. In Grady’s theory, complex metaphors (e.g. LOVE IS A JOURNEY, THEORIES ARE BUILDINGS) are made up of primary metaphors that develop through conflation (the experiential association of discrete conceptual domains). In this theory, journey metaphors are complex forms of the primary metaphor PURPOSES ARE DESTINATIONS, and THEORIES ARE BUILDINGS is the complex form of the more basic metaphors ORGANIZATION IS PHYSICAL STRUCTURE and PERSISTING IS REMAINING ERECT.

Ruiz de Mendoza and Pérez (2011) suggest that an account based on primary metaphors presents two main advantages. First, it has a stronger generalizing power. Thus, the multiplicity of “journey” metaphors (e.g. LOVE/A BUSINESS/A CAREER/A TASK, ETC., IS A JOURNEY) is better explained in terms OF PURPOSES ARE DESTINATIONS. Consider, in this respect, the expression This is getting nowhere, in different contexts of use, such as a problematic business, excessively difficult schoolwork, a failing lab experiment, a couple in crisis, or a debate on a controversial topic, among many other possibilities. What these contexts have in common is the existence of goal-oriented activities, which are seen as steps taken to reach a destination. By accounting for This is getting nowhere 
on the basis of the primary metaphor PURPOSES ARE DESTINATIONS we avoid postulating specific metaphors for every possible target. Second, this more general account traces the source of metaphorical thinking back to the conflation of concepts arising from cooccurring events in experience. This gives metaphor theory pride of place within psychology and the brain sciences (cf. Grady and Johnson 2002). Thus, PURPOSES ARE DESTINATIONS is a primary metaphor that arises from our experience of going to places that we plan to reach. Other examples of primary metaphors (Lakoff and Johnson 1999) are AFFECTION IS WARMTH (based on feeling warm while being held affectionately; e.g. I accepted the warmth of her kiss letting it carry me away ${ }^{\underline{6}}$ ), UNDERSTANDING IS GRASPING (holding and touching an object allows us to get information about it; e.g. He was very good at catching concepts ${ }^{7}$ ), and CHANGE IS motion (based on our correlation of certain locations with certain states, such as being cool in the shade, hot under the sun, and safe at home; e.g. She went from sadness to joy as people shared her pain ${ }^{8}$ ).

\section{II.2. Conceptual Metonymy}

Metonymy is a cognitive process in which one conceptual entity, the vehicle, provides mental access to another conceptual entity, the target, within the same conceptual domain (Kövecses and Radden 1998: 39). Ruiz de Mendoza (2000) distinguishes two basic types of metonymy:

(a) Target-in-source (based on target-source inclusion): a whole domain, the matrix domain, stands for one of its subdomains (e.g. She's taking the pill, where 'pill' stands for 'contraceptive pill');

(b) Source-in-target (based on source-target inclusion): a subdomain stands for its corresponding matrix domain. For example, the expression All hands on deck is a call for all sailors aboard a ship to take up their duties. In this context, "hands" stands for the sailors who do hard physical work on the ship in virtue of the hands playing an experientially prominent role in the domain of labor.

Traditionally accounts of metonymy have taken for granted that there is additional partfor-part relationship, according to which one subdomain within a domain can stand for another subdomain within the same domain. One purported example of this metonymy is RULER FOR ARMY (e.g. Nixon bombed Hanoi; Napoleon lost at Waterloo; Hitler 
invaded Poland). In this metonymy, the ruler and the army are subdomains of the domain of war. However, it may also be argued that the military forces under a ruler's command are a subdomain of our knowledge about the ruler. Another purported case of part-for-part metonymy is provided by the domain of production, in which we have workers and companies as subdomains. For example, in the sentence The company has decided to re-brand itself, it is not the company but some its workers (probably members of a directive board) that have made the decision to give a new name to the company itself. The problem here is that the workers (the metonymic target) are themselves part of the company (the metonymic source), so this metaphor actually qualifies as an example of a target-source inclusion.

A well-known example of apparent "part-for-part” metonymy is CUSTOMER FOR ORDER. According to Taylor (1995: 123), in the sentence The pork chop left without paying, the notions of 'pork chop' and 'customer' are related to each other as parts of the restaurant cognitive model; that is, the two notions are subdomains of the 'restaurant' domain. On the face of it, this explanation of the customer-order relation is convincing. However, setting up one kind of relationship within a broader frame does not mean that there cannot be others. Note that, once placed, an order can be considered part (i.e. a subdomain) of what we know about a customer. For this reason, "the pork chop" in the example above does not stand for any customer but for 'the customer that has ordered a pork chop'. A parallel example is supplied by the usual practice, in hospital contexts, of referring to patients by their medical conditions, the procedures performed on them or the bodily organ that is affected by disease (e.g. the broken arm in the waiting room, the hysterectomy in room 2, the gallbladder in room 241). There is no way in which we could argue that these are cases of “part-for-part” metonymies since a patient's medical condition and his or her treatment are a subdomain of what we know about the patient.

The validity of the source-in-target/target-in-source division has received support from the field of metonymic anaphora (Ruiz de Mendoza and Díez 2004) and zone activation (Geeraerts and Peirsman 2011). Ruiz de Mendoza and Díez (2004) have noticed the existence of a correlation between (i) target-in-source metonymies and cases of metonymic anaphora where there is gender and number (i.e. grammatical) agreement between the anaphoric pronoun and its antecedent, and (ii) source-in-target metonymies and conceptual anaphora (where there is no such gender and number agreement). For 
example, compare The broken arm in the waiting room says he (*it) needs another painkiller urgently (which instantiates the source-in-target metonymy MEDICAL CONDITION FOR PATIENT WITH MEDICAL CONDITION) and Hitler invaded Poland and he (*it/they) paid for it (which instantiates the target-in-source metonymy RULER FOR ARMY). In view of these examples, the source-in-target mapping calls for conceptual anaphora, while the target-in-source one requires grammatical anaphora. However, as amply shown in Ruiz de Mendoza (2000) and Ruiz de Mendoza and Díez (2004), this correlation is merely epiphenomenal. Research has shown that there are a number of principles that interact to account for all cases of metonymic anaphora, among which the most prominent is the Domain Availability Principle (DAP). This principle states that only the matrix (i.e. most encompassing) domain of a metonymic mapping is available for anaphoric reference. In the patient example, the patient, which is the metonymic target, is the matrix domain, whereas in the ruler example, the matrix domain is the metonymic source. Both matrix domains, the patient and the ruler, are the antecedents for the anaphoric operation. Stated in more simple terms, this simply means that metonymic anaphora is always conceptual. Interestingly enough, Geeraerts and Peirsman (2011) have found that source-in-target metonymies do not allow for zeugma, while target-in-source metonymies do. Zeugma is the possibility to assign to the same lexical expression two or more predications that carry different senses. For example, as Geeraerts and Peirsman (2011) observe, "red shirts" in *The red shirts won the match stands for the football players wearing such an outfit as a salient part of their uniform. This is a source-in-target metonymy that cannot be used zeugmatically: *The red shirts won the match and had to be cleaned thoroughly. By contrast, the sentence The book is thick as well as boring allows for zeugma based on two different senses of "book": one, its central (non-metonymic) characterization as a physical object; the other, its noncentral metonymic sense referring to the 'contents of the book'. To us, this analysis additionally suggests that metonymy-based zeugma is also a conceptual phenomenon that combines matrix domain availability and consistency with the metonymic target. In the "red shirts" example, only the "players" domain is available for predication since it is both the matrix domain and the metonymic target. But in the "book" example, where the matrix domain is not a metonymic target, it is possible to set up predications 
involving not only the matrix domain (which supplies the central sense) but also any target subdomain.

The solvency of the source-in-target/ target-in-source distinction, which involves disregarding the existence of "part-for-part" metonymies, is relevant for the ensuing analysis of interaction patterns, where only either of these two metonymic types plays a role.

\section{METAPHOR AND METONYMY IN INTERACTION}

\section{III.1. Metaphtonymy}

As we advanced in the introduction section, Goossens (1990) was the first scholar to enquire into the interaction between metaphor and metonymy. Note that Fauconnier and Turner's (2002) blending theory, which is about conceptual integration, was originally postulated as a question of multiple mental space activation to account for metaphor, analogy and other cognitive phenomena. Metonymy was not explored in its interaction with metaphor but simply postulated as an optimality constraint (because of its associative nature) on the blending of mental spaces termed the Metonymy projection constraint: "When an element is projected from an input to the blend and a second element from that input is projected because of its metonymic link to the first, shorten the metonymic distance between them in the blend” (Turner and Fauconnier 2000: 139). For instance, it is generally accepted that the connection between death and a priest's cowl is large. However, in the representation of Death as a skeleton wearing a priestly cowl, the metonymic connection between the cowl and Death is direct and the two spaces can be straightforwardly integrated.

Let us now discuss the different types of metaphor-metonymy interaction or “metaphtonymy” initially put forward by Goossens (1990):

(i) Metaphor from metonymy, where an original metonymy develops into a metaphor (e.g. to beat one's breast).

(ii) Metonymy within metaphor, as in to bite one's tongue, where the tongue stands for a person's ability to speak; 
(iii) Demetonymization inside a metaphor, as in to pay lip service, where 'lip service', which stands for 'speaking', loses its metonymic import so that the expression makes sense;

(iv) Metaphor within metonymy, which occurs when a metaphor is used in order to add expressiveness to a metonymy, as in to be on one's hind legs, where "hind” brings up the metaphor people are animals.

Even if we acknowledge the originality and elegance of Goossens' work, some remarks need to be made. In the first place, we argue that cases of metaphor from metonymy are in fact cases of metonymic development of a metaphoric source. For example, beating one's breast is a way of making an open show of sorrow; this scenario maps onto other situations where people show sorrow without actually beating their breasts. In the same way, biting one's tongue, rather than a metonymy within a metaphoric framework, is part of a scenario in which someone bites his or her tongue to refrain from revealing a secret or otherwise speaking his or her mind. The expression thus stands for the complete scenario that can then be used as a metaphoric source for other situations where people refrain from speaking without actually biting their tongues. The interaction pattern is the same as the one for beat one's breast. Evidently, both the breast and the tongue are chosen because of their saliency in the domains of emotions and speaking respectively. However, in the expressions under scrutiny neither of these body parts stands for such domains independently of the rest of the expression and their associated scenarios.

We also contend that in pay lip service the metaphor has the idea of 'giving money in return for service' in the source and of 'supporting someone' in the target (cf. That old style bulb has paid service to me for 5 years). Since "lip service" is "service with the lips', where the lips stand for speaking through their salient instrumental role in such an action, "paying lip service” is resolved metaphorically as "supporting someone (just) by speaking” with the implication that service is not supported by facts. The metonymy is thus part of the metaphoric source (paying service with the lips maps onto promising support without the intention of actually giving it), so there is no loss of the metonymic quality of “lip”. 
Finally, we claim that to be on one's hind legs is not a metaphor within a metonymy, but again another case of metonymic development of a metaphoric source in preparation for it to be mapped onto its corresponding target. The source has a situation in which a horse rears up on its hind legs to attack another animal usually out of fear or in selfdefense. The target has a person that defends his or her views emphatically, usually by standing up while gesturing aggressively with his or her hands and fists. The difference with other cases of metonymic development of a metaphoric source is in the linguistic cueing of the metaphorical scenario, which is based on the non-situational metonymic link between "hind legs" and "horse", which initially activates the ontological metaphor people are animals. The activation of this metaphor facilitates the metonymic creation of the situational metaphor described above.

In sum, all examples of Goossens's metaphtonymy are essentially metonymic developments of a situational metaphoric source. However, there are other ways in which metaphor and metonymy interact. Basically, metonymy is subsidiary to -and thus part of- metaphor. Since there two basic metonymic schemas: part-for-whole (sourcein-target) and whole-for-part (target-in-source), this yields four basic interactional patterns:

(i) Metonymic expansion of a metaphoric source

(ii) Metonymic reduction of a metaphoric source

(iii) Metonymic expansion of a metaphoric target

(iv) Metonymic reduction of a metaphoric target

These patterns, which were originally proposed and discussed in Ruiz de Mendoza (1997) and then in Ruiz de Mendoza and Díez (2002), have been productively applied in several recent case studies in the context of multimodality (cf. Hidalgo Downing and Kraljevic Mujic 2011, Urios-Aparisi 2009). Other conceptual interaction patterns involve combinations of metonymies (cf. Ruiz de Mendoza 2000, Ruiz de Mendoza and Mairal 2007, Ruiz de Mendoza and Pérez 2001) and of metaphors (Ruiz de Mendoza and Galera-Masegosa, 2012Ruiz de Mendoza and Mairal 2011). In what follows, we address each of these interaction patterns in turn. 


\section{III.2. Metaphor-metonymy interaction patterns}

This section provides an overview of the patterns of conceptual interaction between metaphor and metonymy originally identified in Ruiz de Mendoza and Díez (2002).

(i) Metonymic expansion of metaphoric source. The metonymy provides a cognitively economical point of access to a complex scenario. Therefore, the metonymy has the function of developing the point-of-access subdomain to the extent required for the metaphor to be possible. Consider the following sentence: He beat his breast and said, 'God, have mercy on me, a sinner' . Here, the brestbeating action in the metaphoric source domain is metonymically expanded onto a situation in which a person beats his breast in order to show his regret about his actions. The target domain of this metonymy is metaphorically mapped onto a situation in which the speaker regretfully shows his sorrow in order to avoid punishment or any other undesired consequences of his behavior.

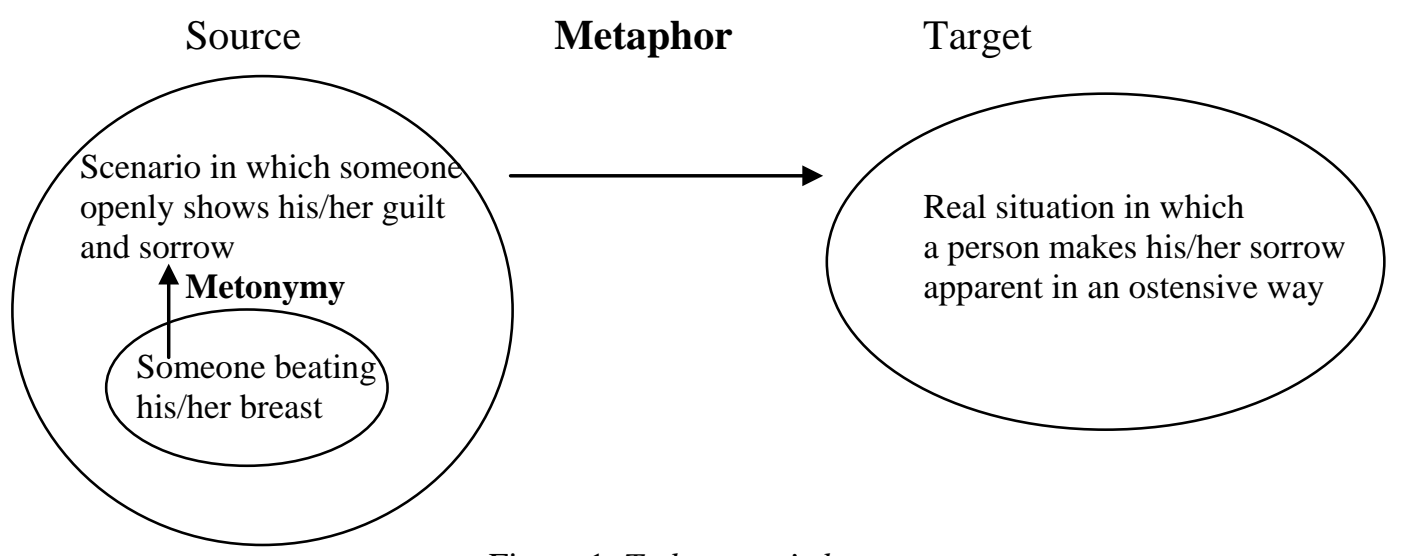

Figure 1. To beat one's breast.

(ii) Metonymic expansion of metaphoric target. The metaphoric source has the function of enhancing the meaning impact of a selected aspect of the target. The metonymy serves to obtain the full range of meaning implications to be derived from the metaphor. For example, the interpretation of the sentence This would already make one knit his eyebrows in suspicion ${ }^{\underline{10}}$ requires setting up a metaphorical correspondence between a person that is knitting articles of clothing (for the source domain) and a person that puts his eyebrows tightly together (for the target domain). The result of this metaphoric mapping needs to be metonymically developed into a situation in which a person frowns as a sign of 
anger. The metonymy that operates within the metaphoric target domain is SIGN FOR STATE.

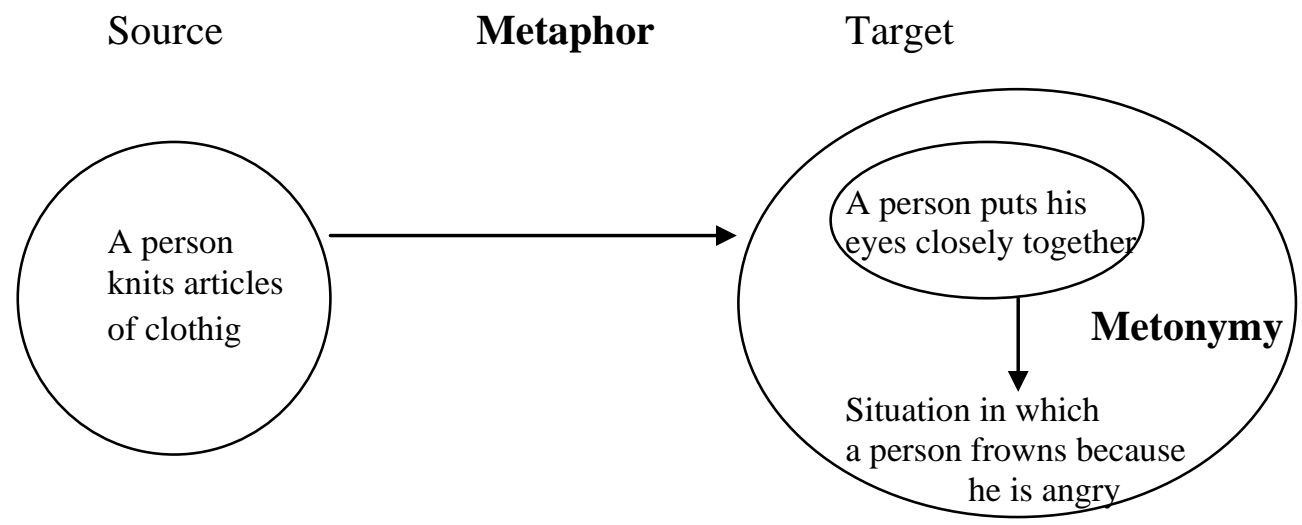

Figure 2. To knit one's eyebrows.

(iii) Metonymic reduction of metaphoric source. The metonymic reduction is a consequence of highlighting the most relevant elements of the metaphoric source, which, in virtue of the mapping, bring our attention to the most relevant aspects of the target, which are seen from the perspective of their corresponding source elements. The sentence To be the life and soul of the party calls for the right attitude and the right actions ${ }^{11}$ calls for an analysis in which one of the aspects within the source domain ('the person') is straightforwardly mapped onto 'the party' in the target domain while 'the life and soul' needs to undergo two consecutive metonymic operations in ordered to be mapped onto 'the most entertaining character of a party' in the target domain.

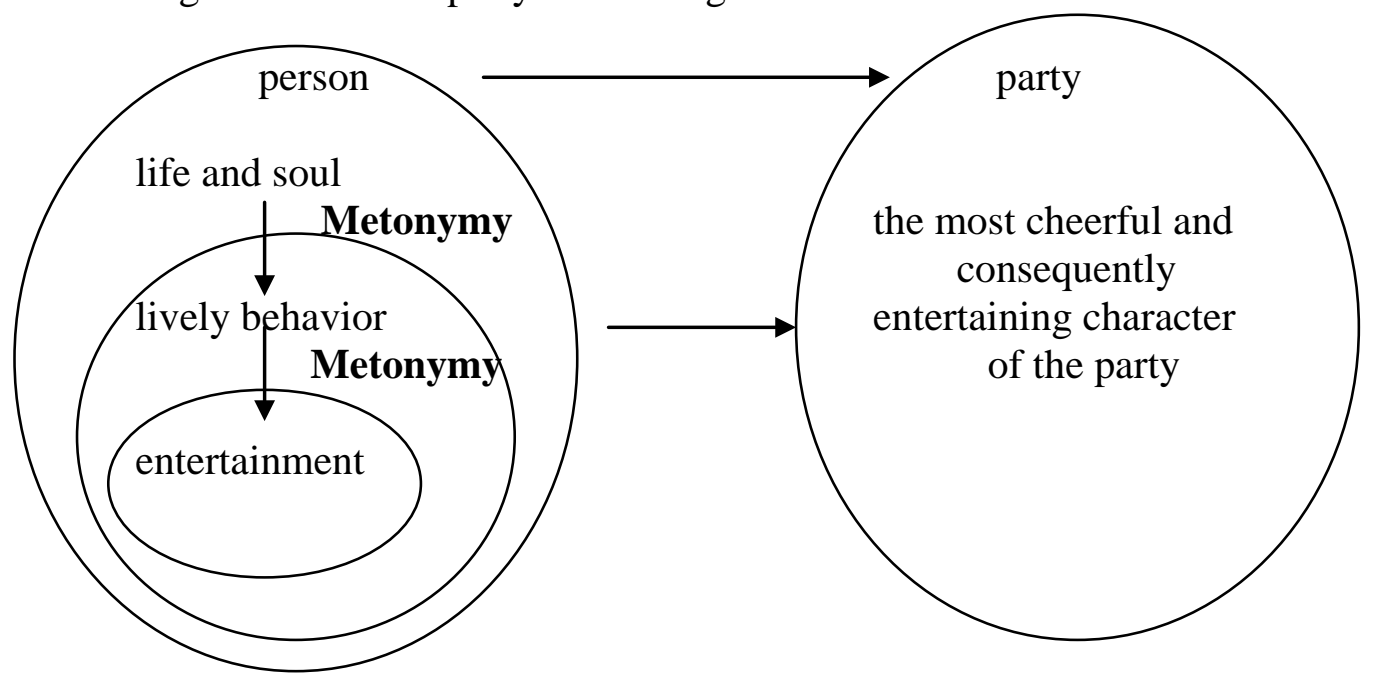

Figure 3. The life and soul of the party. 
A special case of metonymic expansion of the metaphoric source is that of paragons. E.g. Humboldt is the Shakespeare of travelers -as much superior in genius to other travelers as Shakespeare to other poets (cf. Brdar 2007: 111).

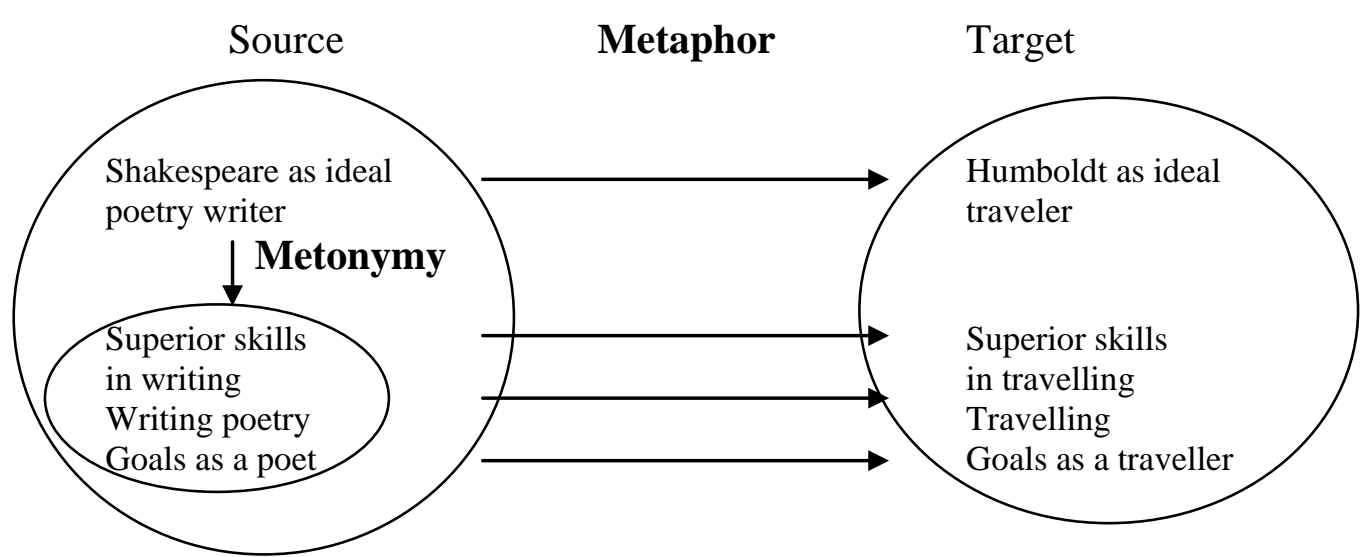

Figure 4. Humboldt is the Shakespeare of travelers.

(iv)Metonymic reduction of metaphoric target. The reduction process allows us to see a target element not only in terms of its corresponding source element but also in terms of the matrix domain against which it is put in perspective. Consider the sentence Over the years, this girl won my heart ${ }^{12}$. In this case, the 'love' scenario is conceptualized as the 'winning' scenario. Two straight-forward correspondences are set between 'winning' and 'the winner' in the source domain and 'obtaining' and 'the lover' in the target. However, once we mapped 'the prize' in the source domain onto 'someone's heart' in the target, a metonymic reduction makes 'someone's heart' to stand for 'someone's love'.

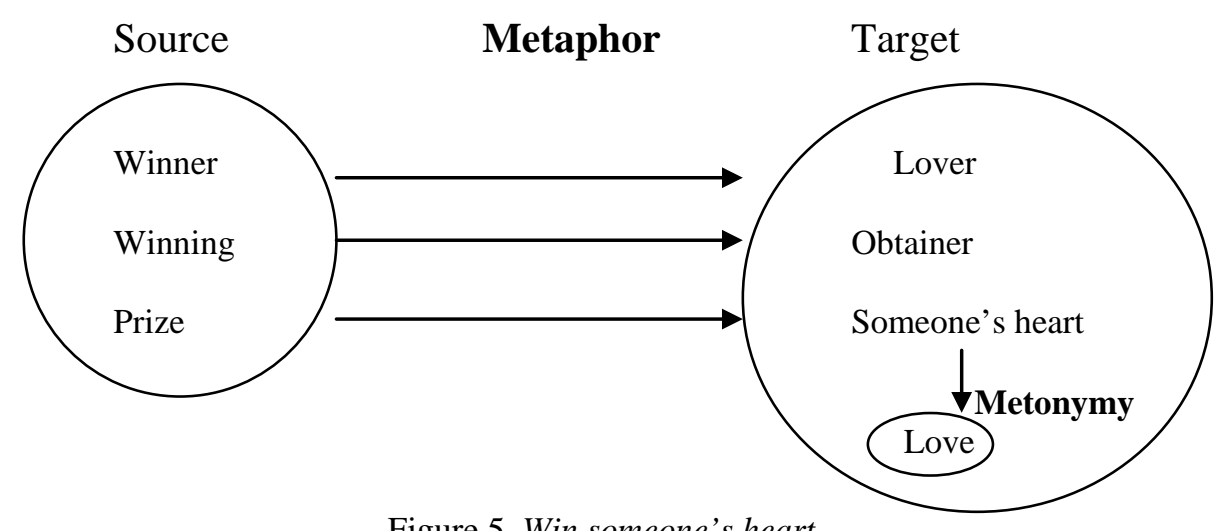

Figure 5. Win someone's heart. 
The sentence He gave me a kick is also interpreted in terms of a metonymic expansion of the metaphoric target. Ruiz de Mendoza (2007) provides an elegant account for the meaning of this expression by postulating that the metonymy CAUSE FOR EFFECT operates within the target domain of the metaphor ACTIONS ARE TRANSFERS OF POSSESSION. In this metaphor, the receiver figuratively "possesses" (i.e. is affected by) the effects of being kicked. The effects are seen as if they were a possession (thus suggesting that the receiver's experience of the effects is not momentaneous). This interpretation overrides Lakoff's (1993) assumption that, since the receiver of the kick is not the possessor of the 'transferred' object, the possession element in the source domain is cancelled out.

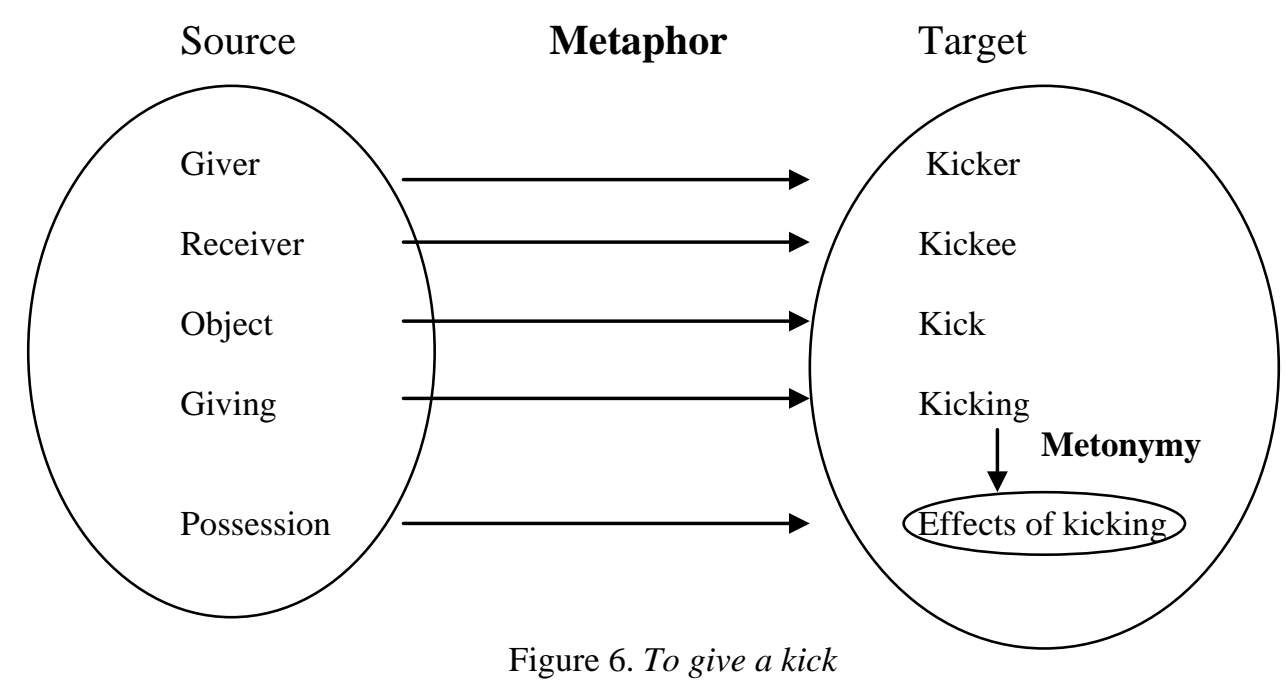

\section{III.3. Metonymic complexes}

This section is devoted to the study of the different ways in which two or more metonymies may interact. Following the analysis in Ruiz de Mendoza (2000, 2007), we distinguish four patterns of metonymic interaction:

(i) Double domain reduction: PLACE FOR INSTITUTION FOR PEOPLE, as in Wall Street is in panic. 


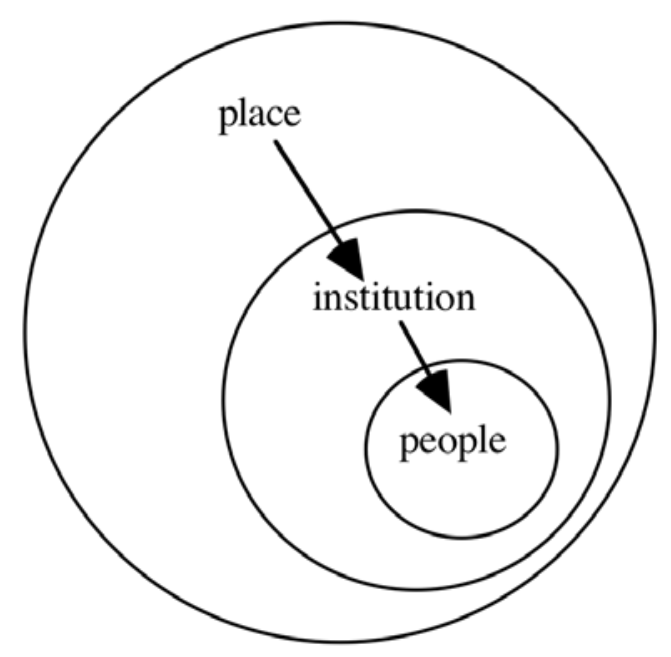

Figure 7. PLACE FOR INSTITUTION FOR PEOPLE.

This metonymy, which is an extension of PLACE FOR INSTITUTION (e.g. Wall Street has always been part of our economy and always will be $\left.e^{\underline{13}}\right)$, is used for economy purposes to identify the people that are associated with an institution that is in turn identified by the place in which it is known to be located. As a consequence of domain reduction both the institution and the people are given prominence (Croft (1993) has referred to such a process by the term "highlighting", which involves giving primary status to a noncentral subdomain of a cognitive model).

(ii) Double domain expansion: HEAD FOR LEADER FOR ACTION OF LEADING, as in His sister heads the policy unit.

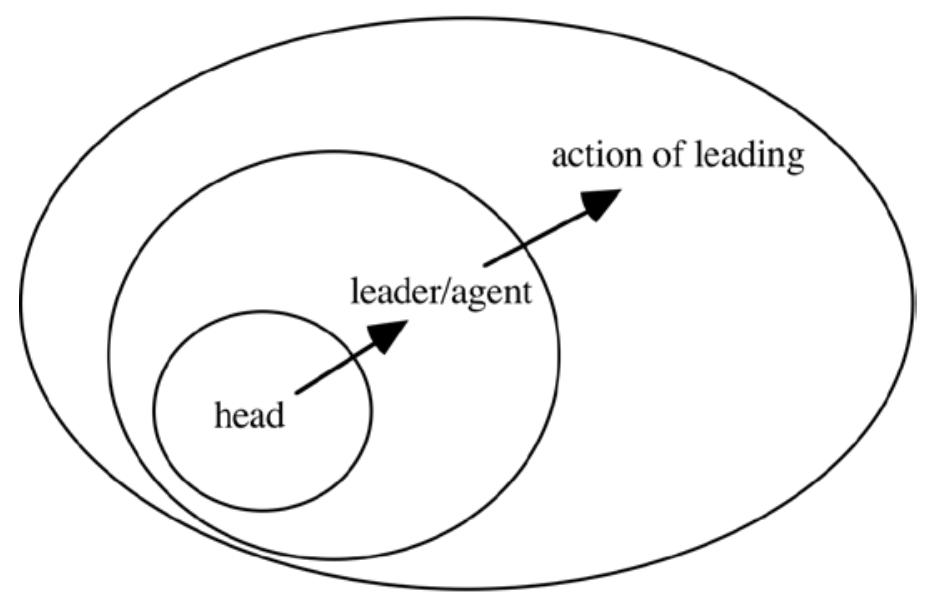

Figure 8. HEAD FOR LEADER FOR ACTION OF LEADING. 
This metonymy underlies a category conversion process of the kind discussed in Ruiz de Mendoza and Pérez (2001). Note that "head" can ultimately stand for the action of leading because of its crucial instrumental role in such an action (the head is prominent in the domain of thinking, which is essential for leadership to be possible).

(iii) Domain reduction plus domain expansion: AUTHOR FOR WORK FOR MEDIUM, as in Shakespeare is on the top shelf.

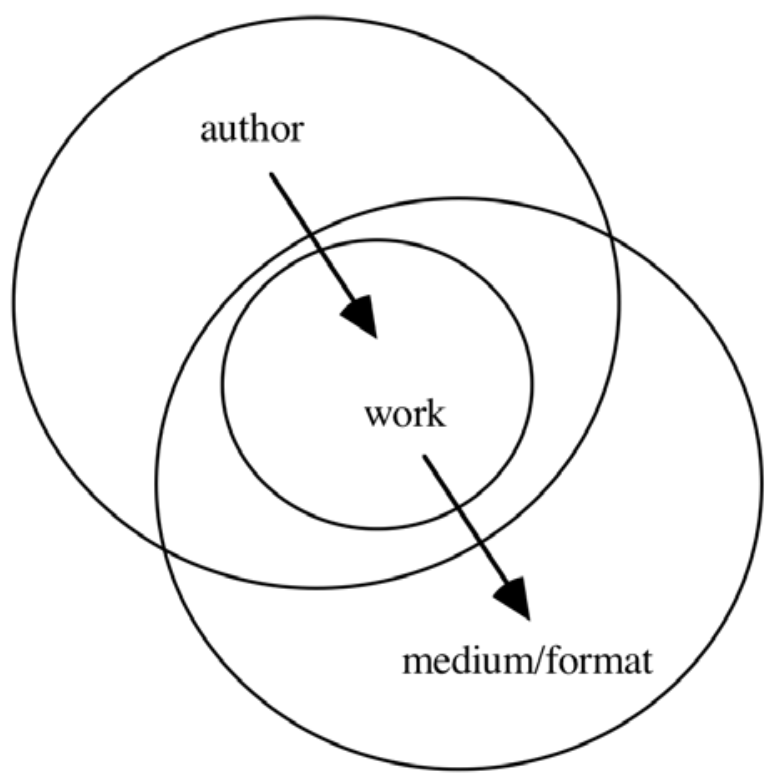

Figure 9. AUTHOR FOR WORK FOR MEDIUM.

This metonymy is but an extension of AUTHOR FOR WORK (e.g. I love reading Shakespeare) where the focus of attention is the literary work, which is understood against the double background of its author and its medium of presentation (e.g. a book).

(iv) Domain expansion plus domain reduction: INSTRUMENT FOR ACTION FOR ABILITY TO PERFORM THE ACTION, as in He has too much lip. 


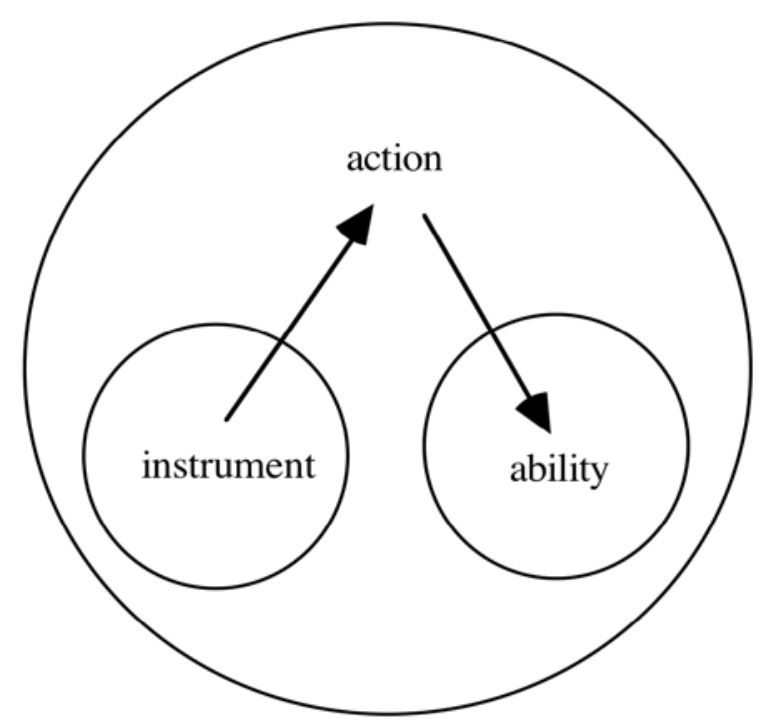

Figure 10. INSTRUMENT FOR ACTION FOR ABILITY TO PERFORM THE ACTION.

A person's lips are prominently instrumental in quickly (and thus deftly) speaking. This instrumental role is the starting point for the first metonymy in the complex. The second metonymy highlights the 'ability' element that is essential to understand the full meaning impact of the expression.

\section{III.3. Metaphoric complexes: amalgams and chains}

Metaphoric complexes may or may not involve the integration of conceptual structure: metaphoric amalgams require the integration of selected aspects from the metaphors that play a role in the process, while in metaphoric chains there are two subsequent metaphoric mappings such that the target of the first mapping becomes the source of the second (cf. Ruiz de Mendoza and Galera-Masegosa 2012, Ruiz de Mendoza and Pérez 2011). Let us see each of them in turn.

\section{III.3.1. Metaphoric amalgams}

The notion of metaphoric amalgam was initially discussed in Ruiz de Mendoza (2008) who simply referred to them as metaphoric complexes - but it has been subsequently developed in Ruiz de Mendoza and Mairal (2011). This kind of metaphoric complex, unlike metaphoric chains, involves the integration of the conceptual material of the 
metaphors that participate in the interaction process. Two types of metaphoric amalgam have been identified so far: single-source metaphoric amalgams and double-source metaphoric amalgams (cf. Ruiz de Mendoza 2007, Ruiz de Mendoza and Mairal 2011). Let us see each of them in turn:

(i) Single-source metaphoric amalgams. These are metaphoric complexes in which the internal structure of one of the metaphors involved merges into the structure of the other. As a result, one of the metaphors becomes part of the source-target structure of another metaphor. An instance of single-source metaphoric amalgam can be found in the sentence She got the idea across to me, which involves two metaphors, IDEAS ARE (MOVING) OBJECTS and UNDERSTANDING AN IDEA IS PERCEPTUALLY EXPLORING AN OBJECT, where the latter is used to enrich the former. This is necessary in order to account for all the meaning implications of the expression since on the basis of IDEAS ARE (MOVING) OBJECTS alone we can only derive the implication that there has been an act of communication whereby the addressee has had access to an idea, but not that he has understood idea. This additional implication is provided by the second metaphor, as captured in Figure 11 below.

\begin{tabular}{|l|l|}
\hline SOURCE $\rightarrow$ & TARGET \\
\hline Causer of motion & Communicator \\
\hline Causing motion & Communicating \\
\hline $\begin{array}{l}\text { Object of caused-motion (moving } \\
\text { object) }\end{array}$ & Idea \\
\hline $\begin{array}{l}\text { Destination of motion (receiver of the } \\
\text { moving object) }\end{array}$ & Addressee \\
\hline Receiving the moving object & Having access to the idea \\
\hline Perceptually exploring the object & Understanding the idea \\
\hline
\end{tabular}

Figure 11. She got the idea across to me.

Consider another example of single-source metaphoric amalgam. In the sentence $\mathrm{He}$ traced my symptoms back to the cause of my disease, there are two metaphors that interact: A DISEASE IS A MOVING OBJECT and RETRACING A MOVING OBJECT IS EXPLAINING THE CAUSE OF A DISEASE. The metaphor A DISEASE IS A MOVING OBJECT allows the conceptualization of an illness as an object traveling along a path. The structure of this metaphor is developed through the integration of the second, which 
specifies the conditions of motion, i.e. the moving object leaves a track that an external observer can retrace in order to identify the origin of motion.

\begin{tabular}{|l|l|}
\hline SOURCE $\rightarrow$ & TARGET \\
\hline Moving object & Disease \\
\hline Motion of object & Progress of disease \\
\hline Source of motion & Cause of disease \\
\hline Destination of motion & Outcome of disease \\
\hline Observer of motion of object (tracer) & $\begin{array}{l}\text { Monitor of progress of disease (e.g. } \\
\text { physician) }\end{array}$ \\
\hline Traces left by moving object & Symptoms of disease \\
\hline Retracing a moving object & Explaining the cause of disease \\
\hline
\end{tabular}

Figure 12. He traced my symptoms back to the cause of my disease.

The same metaphoric interaction operates in the interpretation of He beat me into silence. The metaphor A CHANGE OF STATE IS A CHANGE OF LOCATION is made part of the architecture of the main metaphor, AN EFFECTUAL ACTION IS CAUSED MOTION. The subsidiary metaphor is activated as a requirement of the target domain, which contains a change of state specification (being silent).

\begin{tabular}{|l|l|}
\hline SOURCE (CAUSED MOTION) $\boldsymbol{\rightarrow}$ & TARGET (EFFECTUAL ACTION) \\
\hline Causer of motion & Effector \\
\hline Object of motion & Effectee \\
\hline \multicolumn{1}{|c|}{ Source (change of location) } & Target (change of state) \\
\hline Source of motion & Initial state \\
\hline Destination of motion & Resultant state \\
\hline
\end{tabular}

Figure 13. He beat me into silence.

(ii) Double source metaphoric amalgams. In this case the participating metaphors are at the same level, that is, there is no main-subsidiary relation. The two metaphoric sources are mapped simultaneously onto the same target domain, as in the sentence He beat silence into me. The interpretation of this sentence calls for the interaction of the metaphors ACQUIRING A PROPERTY IS CAUSED-MOTION and ACQUIRING A PROPERTY IS POSSESSING AN OBJECT. These two metaphors intertwine in such a way that the effectee ('me') is conceptualized both as the destination of motion and the new possessor of a transferred object. In turn, the new property ('silence') is seen as a moving object that initially belonged to the causer of motion (the effector) and whose final destination is the effectee. 


\begin{tabular}{|c|c|c|}
\hline $\begin{array}{c}\text { Source } \rightarrow \\
\text { (caused motion) }\end{array}$ & Target & $\begin{array}{c}\leftarrow \text { Source } \\
(\text { possession })\end{array}$ \\
\hline Causer of motion & Effector ('he') & \\
\hline Causing motion & $\begin{array}{l}\text { Effecting ('caused to } \\
\text { acquire') }\end{array}$ & \\
\hline Destination of motion & Effectee ('me') & $\begin{array}{l}\text { New possessor of an } \\
\text { object }\end{array}$ \\
\hline \multirow{2}{*}{$\begin{array}{l}\text { Object of caused- } \\
\text { motion (moving object) }\end{array}$} & New property ('silence’) & \\
\hline & $\begin{array}{l}\text { Resultant state } \\
\text { ('acquiring the new } \\
\text { property of silence') }\end{array}$ & $\begin{array}{l}\text { Gaining possession of } \\
\text { an object }\end{array}$ \\
\hline $\begin{array}{l}\text { Manner of causing } \\
\text { motion }\end{array}$ & $\begin{array}{l}\text { Manner of effecting } \\
\text { ('beating') }\end{array}$ & \\
\hline
\end{tabular}

Figure 14. He beat silence into me.

There are certain cases in which a metonymy is built into the target domain of a doublesource metaphoric amalgam, as in He burst into tears. The interpretation of this phrasal verb involves the integration of two metaphors, namely EMOTIONAL DAMAGE IS PHYSICAL DAMAGE and EMOTIONAL DAMAGE IS MOTION. Here, we conceptualize the process of experiencing emotional damage both in terms of suffering physical damage ('bursting') combined with motion (moving into a given place), which is used to indicate a change of state on the basis of the primary metaphor (cf. Grady 1997) A CHANGE OF STATE IS A CHANGE OF LOCATION. The outcome of the process of bursting is mapped onto the symptoms of emotional damage, namely tears. Then, through the EFFECT FOR CAUSE metonymy the tears (the effect) are made to stand for the final state of emotional damage (the cause). Additionally, the initial state (in which the person has not suffered emotional damage) and the final state (in which the person has suffered emotional damage) are identified with the source and destination of motion respectively.

\begin{tabular}{|c|c|c|}
\hline $\begin{array}{c}\text { Source } \rightarrow \\
\text { (bursting) }\end{array}$ & $\begin{array}{c}\text { Target } \\
\text { (change of state) }\end{array}$ & $\begin{array}{c}\leftarrow \text { Source } \\
\text { (change of location) }\end{array}$ \\
\hline $\begin{array}{c}\text { Process of suffering } \\
\text { physical damage } \\
\text { (bursting) }\end{array}$ & $\begin{array}{c}\text { Process of experiencing } \\
\text { emotional damage }\end{array}$ & Motion \\
\hline & $\begin{array}{c}\text { Initial state (no emotional } \\
\text { damage) }\end{array}$ & Source of motion \\
\hline & $\begin{array}{c}\text { Final state (emotional } \\
\text { damage) } \\
\text { Broken pieces }\end{array}$ & Destination of motion \\
\hline & Symptoms of emotional & \\
\hline
\end{tabular}

Figure 15. He burst into tears. 


\section{III.3.2. Metaphoric chains}

As we advanced in the introduction section, a metaphoric chain is an interactional pattern between two metaphors in which the target domain of one metaphor becomes the source of a subsequent metaphor. Let us examine the interpretation of some phrasal verbs using this pattern of interaction. Consider the sentence [When] they broke away from our church, I stuck to my own $n^{14}$. The source domain of the first metaphoric mapping is provided by the semantics of the phrasal verb break away: an object is broken into two or more pieces, and these pieces become separated from one another. This first metaphoric domain is mapped onto a target domain in which two people (or a person/some people and a given institution) become physically separated. The target domain constitutes the source of a second metaphor, whose target domain is the nonphysical separation. The last metaphoric mapping is grounded in experiential conflation: the fact that two people or a person and an institution are no longer together (either in a relationship or in institutional terms) generally correlates with physical separation.

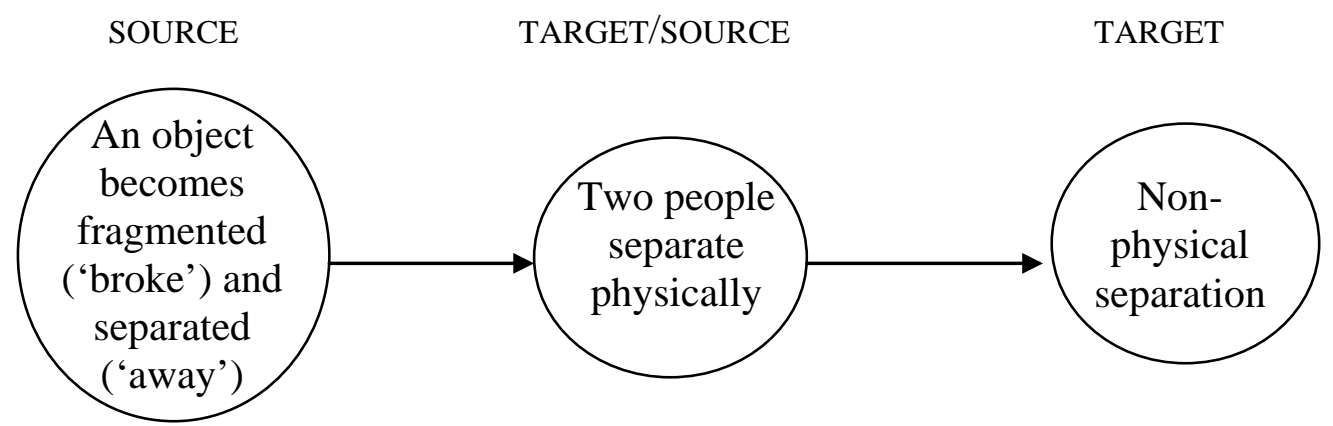

Figure 16. [When] they broke away from our church, I stuck to my own.

We also need the use of a metaphoric chain in the interpretation of the phrasal verb 'break down' as in the sentence When she died Papa broke down and cried ${ }^{15}$. The source domain of the first metaphorical process arises from the combined semantic structure of the verb and the particle, that is, physical fragmentation ('break') and loss of functionality ('down'). This conceptual material is mapped onto another domain in which there is no physical fragmentation, but there is an object that becomes dysfunctional (as in My car broke down). The implication of dysfunctionality in the first target domain maps onto a situation in which a person becomes emotionally distressed and therefore looses control over himself. This process is schematized as follows: 


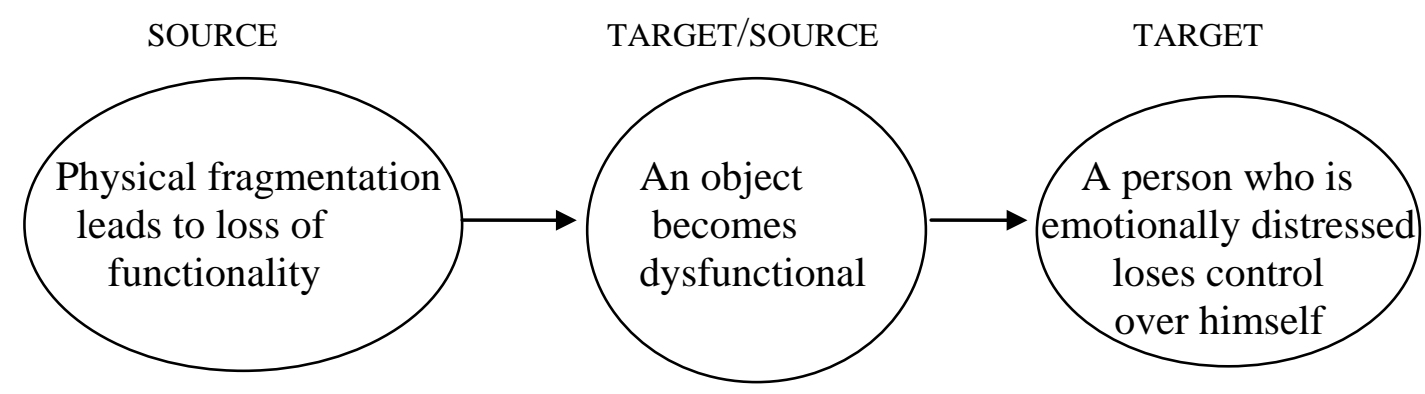

Figure 17. When she died Papa broke down and cried.

Our corpus of phrasal verbs has revealed that some of them may have different (although related) interpretations. This is the case of 'give away'. The default interpretation of this phrasal verb is to give an object that one possesses to someone else for free, and not caring much about the future of the donated object (as in She gave everything away, including her home ${ }^{16}$ ). The idea of getting rid of an object (or a number of them) is found in the source domain of the first metaphor, which is mapped onto the target domain in which someone gets rids of a person as if he/she were an object. This idea is then mapped onto a final target domain that contains the action of betraying a person. This last metaphoric mapping is conceptually reinforced by the negative feelings that a person would develop towards the person who would 'give him away' as if he/she actually were an object.

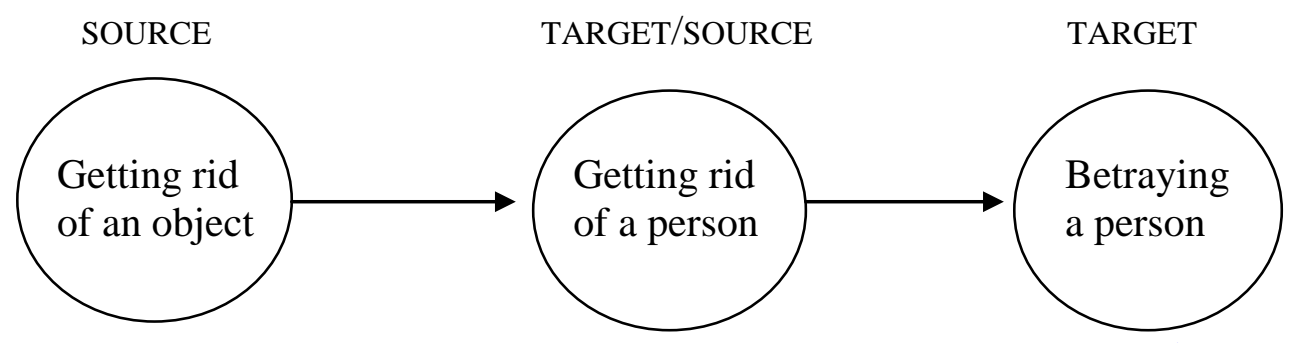

Figure 18. Well, how soon we were betrayed, your sister gave us away ${ }^{17}$.

An alternative interpretation of this phrasal verb arises when the person given away is the bride in the context of a wedding. In this case, the bride is generally walked down the aisle (in order to be "given away”) by her father. This particular interpretation does not convey the idea that the initial possessor of the object donates it to whoever may take it, not caring about it anymore (which is the base for the negative feeling that gives rise to the 'betraying' interpretation). In the case of the bride, his father transfers the responsibility of taking care of her to the husband-to-be (e.g. The father of the bride was 
absent on duty with the Merchant Marine, so the bride was given away by his friend Harry Gibson of San Francisco $\left.{ }^{18}\right)$.

Our last example shows that metaphoric chains may also interact with metonymy. Consider the sentence Eventually someone got fed up with her behavior and called the cops $^{19}$. A first step in the interpretation of the phrasal verb to be fed up with is the application of the basic metaphors FULL IS UP, which is combined with the imageschema THE HUMAN BODY IS A CONTAINER. These two underlying metaphors allow us to map 'to be fed up' onto 'to be filled to the top with food'. Then we need to metonymically expand this target domain onto a more complex situation in which a person cannot have more food or will get sick. This elaborated target domain constitutes the source of another metaphor whose target domain is a situation in which a person cannot stand someone else's behavior (see figure 19 below).

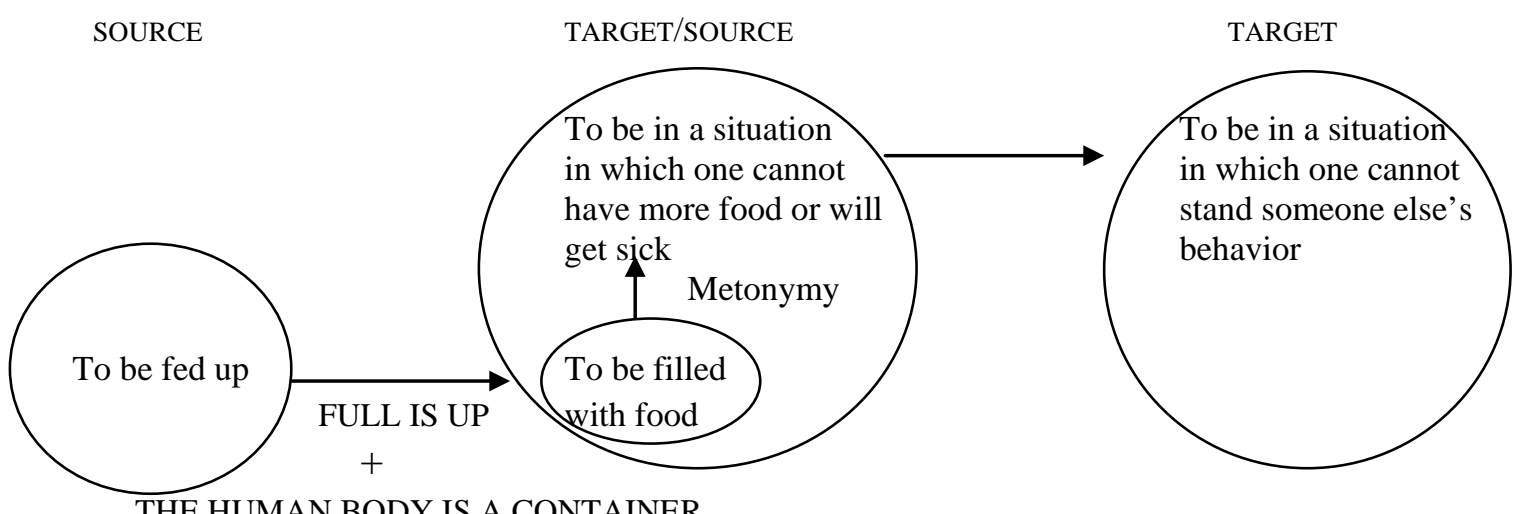

Figure 19. Eventually someone got fed up with her behavior and called the cops.

\section{CONCLUSIONS}

Phrasal verbs are idiomatic constructions consisting of fixed and variable parts where the fixed part can take a degree of variation that stems from the general ability of verbal structure to be fused into various argument structure constructions (e.g. $X$ breaks away with $Y$; $X$ and $Y$ break away) and to take tense, aspect and other grammatical markers.

The conceptual make-up of phrasal verbs goes beyond the combination of verbal meaning (whether propositional or image schematic) and the image schematic meaning associated with the adverbial particle or the preposition. It may require the combination 
of two metaphors (which in turn may include cases of metonymic activation) either in the form of amalgams or chains.

Such combinations account for an essential part of the conventional implications derived from phrasal verbs. In turn, such implications are what renders the meaning of phrasal verbs, like the meaning of other idiomatic constructions, fundamentally noncompositional although largely predictable and calculable.

\section{Notes}

${ }^{1}$ Center for Research in the Applications of Language (www.cilap.es). Financial support for this research has been provided by the Spanish Ministry of Science and Innovation, grant no. FFI2010-17610/FILO.

$\underline{2}$ http://www.lifescript.com/life/relationships/hang-ups/6_reasons_you cant leave_a loser.aspx. Accessed on November 19, 2011.

${ }^{3}$ http://www.survivalistboards.com/showthread.php?t=77704. Accessed on November 19, 2011.

${ }^{4}$ www.alplm.org/abraham-lincoln-greatest-paraphrases/ Accessed on November 19, 2011.

5 http://scientopia.org/blogs/goodmath/2011/02/11/another-crank-comes-to-visit-the-cognitive-theoreticmodel-of-the-universe/. Accessed on November 19, 2011.

${ }^{6}$ http://www.nicestories.com/unreg/s/story.php?id=6975. Accessed on November 19, 2011.

${ }^{7}$ http://lifenetintl.org/pdfs/RAYFORD.pdf. Accessed on November 19, 2011.

8 http://covenant-hopeliveshere.blogspot.com/2008/06/god-speaks-to-his-children.html. Accessed on December 3, 2011.

${ }^{9}$ http://bible.cc/luke/18-13.htm. Accessed on November 23, 2011.

${ }^{10}$ http://www.amazon.ca/product-reviews/1586632043. Accessed on November 23, 2011.

11 http://www.hypnosisdownloads.com/enjoy-life/life-soul. Accessed on November 23, 2011.

12 http://www.lomography.es/magazine/reviews/2011/03/22/for-the-ahem-love-of-lomography-black-andwhite-120-film. Accessed on November 23, 2011.

$\underline{13}$ http://nycapitolnews.com/wordpress/2011/10/occupied-or-not-wall-street-is-sagging/. Accessed on December 3, 2011.

14 http://books.google.es/books?id=l3C97GdNz9oCandpg=PA44andlpg=PA44anddq=\%22when + they + broke+away\%22andsource=blandots=1pajL7oE_Aandsig=JQT6hM8pbgKeue6oRLUv00Bn6wcandhl=e andei=W-LLTr3uKMrc8AP0sIkHandsa=Xandoi=book_resultandct=resultandresnum=2andved= 0CCUQ6AEwATgK\#v=onepageandq $=\% 22$ when $\% 20$ they\%20broke\%20away\%22andf $=$ false. . Accessed on November 23, 2011.

$\underline{15}$ http://lyricsplayground.com/alpha/songs/p/papa.shtml. Accessed on November 23, 2011.

${ }^{16}$ http://www.comeandseeicons.com/w/drz05.htm. Accessed on November 23, 2011.

${ }^{17}$ http://www.metrolyrics.com/o-valencia-lyrics-decemberists.html. Accessed on November 23, 2011.

${ }^{18} \mathrm{http}: / /$ news.google.com/newspapers?nid=1970anddat=19431007andid=ODUyAAAAIBAJandsjid=ZeM FAAAAIBAJandpg=2821,491682. Accessed on November 23, 2011.

19 http://www.canada.com/story_print.html?id=e33c79ba-e5ef-479d-a59a-43bd5e9e6b52andsponsor=. Accessed on November 23, 2011. 


\section{REFERENCES}

Brdar, M. 2007. Metonymy in Grammar. Towards Motivating Extensions of Grammatical Categories and Constructions. Osijek: Faculty of Philosophy, Josip Juraj Strossmayer University.

Croft, W. 1993. "The role of domains in the interpretation of metaphors and metonymies”. Cognitive Linguistics, 4, 335-370.

Dirven, R. 2001. “English phrasal verbs: Theory and didactic application”. In Pütz, M., S. Niemeier and R. Dirven (Eds.) Applied Cognitive. Linguistics II: Language Pedagogy. Berlin/New York: Mouton de Gruyter, 3-28.

Fauconnier, G. and Turner, M. 1996. “Blending as a central process in grammar”. In Goldberg, A. (Ed.) Conceptual Structure, Discourse, and Language. Stanford: Cambridge University Press, 113-130.

Fauconnier, G. and Turner, M. 2002. The Way We Think: Conceptual Blending and the Mind's Hidden Complexities. New York: Basic Books.

Galera-Masegosa, A. 2010. “A cognitive approach to the analysis of simile-based idiomatic expressions”. Círculo de Lingüística Aplicada a la Comunicación, 43, 3-48.

Geeraerts, D. and Peirsman, Y. 2011. "Zones, facets, and prototype-based metonymy”. In Benczes, R., A. Barcelona and F.J. Ruiz de Mendoza (Eds.) Defining Metonymy in Cognitive Linguistics: Towards a consensus view. Amsterdam: John Benjamins, 89-102.

Gibbs, R. 1994. The Poetics of the Mind. Cambridge: Cambridge University Press.

Gibbs R., Bogdonovich, J., Sykes, J. and Barr, D. 1997. "Metaphor in idiom comprehension”. Journal of Memory and Language, 37, 141-154.

Goossens, L. 1990. "Metaphtonymy: the interaction of metaphor and metonymy in expressions for linguistic action”. Cognitive Linguistics, 1 (3), 323-340.

Grady, J. 1997. Foundations of Meaning: Primary Metaphors and Primary Scenes. Ph. D. dissertation, Berkeley: University of California. 
Grady, J. 1999. “A typology of motivation for conceptual metaphor: correlation vs. resemblance”. In Gibbs, R. and G. Steen (Eds.) Metaphor in Cognitive Linguistics. Amsterdam/Philadelphia: John Benjamins, 79-100.

Grady, J. and Johnson, C. 2002. "Converging evidence for the notions of subscene and primary scene”. In Dirven, R. and R. Pörings (Eds.) Metaphor and Metonymy in Comparison and Contrast. Berlin/New York: Mouton de Gruyter, 533-553.

Hampe, B. (2000): “Facing up to the meaning of 'face up to': A cognitive semanticopragmatic anaysis of an English verb-particle construction”. In Foolen, A. and F. van der Leek (Eds.) Constructions in Cognitive Linguistics. Amsterdam/ Philadelphia: John Benjamins, 81-101.

Hidalgo Downing, L. and Kraljevic Mujic, B. 2011. "Multimodal metonymy and metaphor as complex discourse resources for creativity in ICT advertising discourse”. In Gonzálvez-García, F., S. Peña and L. Pérez (Eds.) Metaphor and Metonymy Revisited beyond the Contemporary Theory of Metaphor. Amsterdam/Philadelphia: John Benjamins, 153-178.

Kövecses, Z. 1990. Emotion Concepts. New York: Springer-Verlag.

Kövecses, Z. 2000. Metaphor and Emotion: Language, Culture, and Body in Human Feeling. Cambridge/New York: Cambridge University Press.

Kövecses, Z. 2002. Metaphor. A Practical Introduction. Oxford/New York: Oxford University Press.

Kövecses, Z. 2005. Metaphor in Culture. Universality and Variation. Cambidge/New York: Cambridge University Press.

Kövecses, Z. and Radden, G. 1998. "Metonymy: Developing a cognitive linguistic view”. Cognitive Linguistics, 9, 37-77.

Kövecses, Z. and Szabó, P. 1996. “Idioms: A view from cognitive semantics”. Applied Linguistics, 17 (3), 326-355.

Kuiper, K. and Everaert, M. 2004. "Limits on the phrase structural configurations of phrasal lexemes”. EUROPHRAS 2000. Tübingen: Stauffenburg Verlag, 257-262. 
Lakoff, G. 1987. Women, Fire, and Dangerous Things: What Categories Reveal About the Mind. Chicago: University of Chicago Press.

Lakoff, G. 1993. “The contemporary theory of metaphor”. In Ortony, A. (Ed.) Metaphor and Thought, 2nd ed., Cambridge, Mass.: Cambridge University Press, 202-251.

Lakoff, G. and Johnson, M. 1980. Metaphors We Live by. Chicago: Chicago University Press.

Lakoff, G. and Johnson, M. 1999. Philosophy in the Flesh. New York: Basic Books.

Lakoff, G. and Turner, M. 1989. More than Cool Reason. A Field Guide to Poetic Metaphor. Chicago and London: The University of Chicago Press.

Langlotz, A. 2006. Idiomatic Creativity: A Cognitive-Linguistic Model of IdiomRepresentation and Idiom-Variation in English. Amsterdam/Philadelphia: John Benjamins.

Makkai, A. 1972. Idiom structure in English. The Hague: Mouton de Gruyter.

Narayanan, S. 1997. Embodiment in Language Understanding: Sensory-Motor Representations for Metaphoric Reasoning about Event Descriptions. Ph. D. dissertation, Departments of Computer Science, Berkeley: University of California.

Ruiz de Mendoza, F.J. 1997. "Metaphor, metonymy and conceptual interaction”. Atlantis, 19, 281 - 295.

Ruiz de Mendoza, F.J. 2000. "The role of mappings and domains in understanding metonymy”. In Barcelona, A. (Ed.) Metaphor and Metonymy at the Crossroads. Berlin/New York: Mouton de Gruyter, 109-132.

Ruiz de Mendoza, F.J. 2007. "High level cognitive models: In search of a unified framework for inferential and grammatical behavior”. In Kosecki, K. (Ed.) Perspectives on Metonymy. Frankfurt/Main: Peter Lang, 11-30.

Ruiz de Mendoza, F.J. and Díez, O. 2002. "Patterns of conceptual interaction”. In Dirven, R. and R. Pörings (Eds.) Metaphor and Metonymy in Comparison and Contrast. Berlin/New York: Mouton de Gruyter, 489-532. 
Ruiz de Mendoza, F.J. and Díez, O. 2004. "Metonymic motivation in anaphoric reference”. In Radden, G. and K.-U. Panther (Eds.) Studies in Linguistic Motivation. Berlin and New York: Mouton de Gruyter, 293-320.

Ruiz de Mendoza, F.J. and Galera-Masegosa, A. 2012. "Metaphoric and metonymic complexes in phrasal verb interpretation: metaphoric chains”. In Eizaga Rebollar, B. (Ed.) Studies in Cognition and Linguistics. Frankfurt: Peter Lang, 161-190.

Ruiz de Mendoza, F.J. and Mairal, R. 2007. "High-level metaphor and metonymy in meaning construction”. In Radden, G., K-M. Köpcke, T. Berg and P. Siemund (Eds.) Aspects of Meaning Construction. Amsterdam/Philadelphia: John Benjamins, 33-51.

Ruiz de Mendoza, F.J. and Mairal, R. 2008. "Levels of description and constraining factors in meaning construction: An introduction to the Lexical Constructional Model”. Folia Linguistica, 42 (2), 355-400.

Ruiz de Mendoza, F.J. and Mairal, R. 2011. "Constraints on syntactic alternation: lexical-constructional subsumption in the Lexical-Constructional Model”. In Guerrero, P. (Ed.) Morphosyntactic Alternations in English. Functional and Cognitive Perspectives. London, UK/Oakville, CT: Equinox, 62-82.

Ruiz de Mendoza, F.J. and Pérez, L. 2001. "Metonymy and the grammar: motivation, constraints and interaction”. Language and Communication, 21 (4), 321-357.

Ruiz de Mendoza, F.J. and Pérez, L. 2003. “Cognitive operations and pragmatic implication”. In Panther, K.-U. and L. Thornburg (Eds.) Metonymy and Pragmatic Inferencing. Amsterdam/Philadelphia: John Benjamins, 23-50.

Ruiz de Mendoza, F.J. and Pérez, L. 2011. “The Contemporary Theory of Metaphor: myths, developments and challenges”. Metaphor and Symbol, 26, 161-185.

Taylor, J. 1995. Linguistic Categorization. Prototypes in Linguistic Theory. Oxford: Clarendon Press.

Turner, M. and Fauconnier, G. 2000. “Metaphor, metonymy, and binding” In Barcelona, A. (Ed.) Metaphor and Metonymy at the Crossroads. Berlin: Mouton de Gruyter, 133-145. 
Urios-Aparisi, E. 2009. "Interaction of multimodal metaphor and metonymy in TV commercials: Four case studies”. In Forceville, C. and E. Urios-Aparisi (Eds.) Multimodal Metaphor. Berlin/New York: Mouton de Gruyter, 95-118.

Received November 2011

Cite this article as:

Ruiz de Mendoza, F.J. and Galera-Masegosa, A. 2011. “Going beyond metaphtonymy: Metaphoric and metonymic complexes in phrasal verb interpretation”. Language Value, 3 (1), 1-29. Jaume I University ePress: Castelló, Spain. http://www.e-revistes.uji.es/languagevalue.

ISSN 1989-7103

Articles are copyrighted by their respective authors 